\title{
CIRCULATING OESTROGENS AND PROGESTERONE IN THE BOVINE AFTER SYNCHRONIZATION WITH MELENGESTROL ACETATE
}

\author{
HILARY DOBSON, L. J. BOYD* AND D. EXLEY $\dagger$ \\ Department of Veterinary Clinical Studies, University of Liverpool, and \\ A.R.C. Institute for Research on Animal Diseases, Compton, Berks.
}

(Received 13th March 1972)

Summary. Five Friesian maiden heifers and four Friesian or Ayrshire cows were assigned to each of four treatments, namely: (1) controls; (2) melengestrol acetate (MGA) $1 \mathrm{mg}$ orally daily for 14 days; (3) MGA + 2500 i.u. HCG at $72 \mathrm{hr}$ after the last administration of MGA; and (4) MGA $+0.5 \mathrm{mg}$ oestradiol benzoate on Day 1 of MGA treatment, +2500 i.u. PMSG at $36 \mathrm{hr}+2500$ i.u. HCG at $72 \mathrm{hr}$ after the last administration of MGA.

Jugular vein blood was sampled daily over the oestrus period in the control animals and daily after the last dose of MGA until the day after the first oestrus. The concentrations of progesterone and total oestrogens in peripheral plasma samples were assayed by radioimmunoassay without chromatographic separation.

In the control animals, the total oestrogen concentration increased from $7 \mathrm{pg} / \mathrm{ml} 4$ days before oestrus to $14 \mathrm{pg} / \mathrm{ml}$ on the day of oestrus, then decreased to $9 \mathrm{pg} / \mathrm{ml} 1$ day after oestrus. Treatment with MGA alone did not alter this pattern at the first synchronized oestrus. Administration of HCG $72 \mathrm{hr}$ after MGA withdrawal apparently depressed total oestrogen concentration. This was counteracted by prior treatment with PMSG. A comparison of the data from animals receiving MGA only and from controls indicates no adverse effect on release of oestrogens from ovarian follicles after cessation of MGA treatment.

The progesterone concentration in control animals decreased from $9 \mathrm{ng} / \mathrm{ml} 4$ days before oestrus to $0.35 \mathrm{ng} / \mathrm{ml}$ on the day of oestrus. The MGA-treated animals had low progesterone values for several days before oestrus. Three of the sixteen animals treated with gonadotrophins had progesterone concentrations higher than basal values.

\section{INTRODUCTION}

Melengestrol acetate (MGA) is a potent progestagen that has been used to synchronize oestrus in beef and dairy cattle (Zimbelman \& Smith, 1966a, b;

*Visiting Professor with the Milk Marketing Board-on leave from Michigan State University, U.S.A.

$\dagger$ Present address: Department of Biochemistry, Queen Elizabeth College, London. 
Roussel, Beatty \& Smith, 1969; Boyd, 1970). A high percentage of treated animals show oestrous behaviour during the short period following withdrawal of MGA but fertility at this first synchronized oestrus is low. A disturbance in the hormonal balance during the immediate post-treatment period may be important among the factors responsible for the low conception. The measurement of oestrogens in peripheral plasma may be taken as an index of follicular activity, and that of progesterone as a guide to corpus luteum function; using these parameters, we have attempted to determine the effect of MGA treatment on the production of total oestrogens and progesterone.

\section{MATERIALS AND METHODS}

Twenty Friesian maiden heifers and sixteen Friesian and Ayrshire cows were used in the study. The heifers ranged from 14 to 25 months of age and from 300 to $468 \mathrm{~kg}$ in body weight; the cows were from 29 to 49 months of age and had been in their current lactations from 30 to 118 days. The animals were housed in tied-standings but were turned out daily into an enclosed exercise area for about $4 \mathrm{hr}$. All animals were fed individually and the cows were milked twice daily.

Five heifers and four cows were assigned to each of four treatment groups: (1) controls, which received no progestagen or gonadotrophin; (2) MGA; (3) MGA + HCG (Lutormone, Burroughs Wellcome) at $72 \mathrm{hr}$ after the last administration of MGA; and (4) MGA +oestradiol benzoate on Day 1 of MGA treatment, + PMSG (Burroughs Wellcome) at $36 \mathrm{hr}$, + HCG at $72 \mathrm{hr}$ after last dose of MGA.

One mg of MGA was mixed with $0.9 \mathrm{~kg}$ of the regular concentrate ration and this cubed mixture was consumed daily for 14 days by each of the animals in the three progestagen-treated groups. The control animals and those which received MGA only were inseminated at $12 \mathrm{hr}$ and again at $24 \mathrm{hr}$ after the onset of observed oestrus. Animals in the MGA + HCG group were injected subcutaneously with 2500 i.u. HCG at $72 \mathrm{hr}$ after the last dose of MGA and were then inseminated at 12 and $24 \mathrm{hr}$ after HCG administration. Each animal in the remaining treatment group was injected subcutaneously with $0.5 \mathrm{mg}$ oestradiol benzoate on the first day of MGA feeding to cause early regression of the corpus luteum (Wiltbank \& Kasson, 1968); following the last administration of MGA, each animal was given 2500 i.u. PMSG at $36 \mathrm{hr}$ and 2500 i.u. HCG at $72 \mathrm{hr}$, and then inseminated 12 and $24 \mathrm{hr}$ after HCG administration.

All animals were observed closely for standing oestrus each morning in the exercise area and at least once in the afternoon in the tied-standings for signs such as mucus, red swollen vulva, nervous behaviour and post-oestrual bleeding. Ovulation was not confirmed by rectal palpation.

Blood from the jugular vein of each animal was collected daily in heparinized tubes and spun down immediately to separate the plasma, which was then stored at $-15^{\circ} \mathrm{C}$ until analysis. Samples from control animals were collected for 4 days before oestrus, on the day of oestrus and the day after oestrus. For the MGA-treated animals, blood was collected daily after MGA withdrawal until the day after oestrus or until the day of last insemination. 
The total oestrogen concentration in the plasma was assessed by assaying, in duplicate, the dried diethyl-ether extract from $5 \mathrm{ml}$ plasma according to the liquid radioimmunoassay method of Hotchkiss, Atkinson \& Knobil (1971). The dried diethyl-ether extract was not subjected to chromatographic separation before assay. This method of analysis was used near its limit of sensitivity, due to the exceptionally low concentration of oestrogen in normal bovine blood, but the coefficient of variation for standard duplicates was $5.6 \%$ and for sample duplicates, $12.5 \%$.

The progesterone concentration was also assessed by radioimmunoassay of hexane extracts with a specific antibody to progesterone.

\section{RESULTS}

Blood samples were assayed from six control animal (four heifers and two cows) and the pattern of total oestrogens with respect to time is shown in Text-fig. 1. The concentration rose from an average of $7 \mathrm{pg} / \mathrm{ml}$ (S.D. \pm 1.8 ) 4 days before the onset of oestrus to a maximum of $14 \mathrm{pg} / \mathrm{ml}( \pm 2 \cdot 6)$ on the day of oestrus,

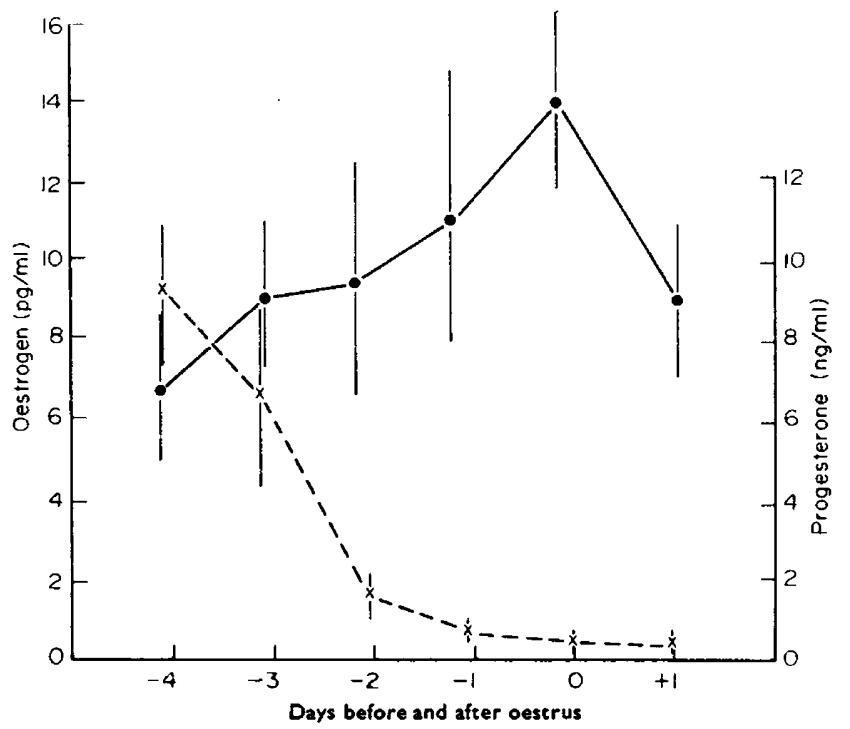

TEXT-Fic. 1. Total oestrogen $(\bullet)$ and progesterone $(x)$ pattern before and after oestrus in control animals (four heifers and two cows).

then decreased to $9 \mathrm{pg} / \mathrm{ml}( \pm 2 \cdot 2)$ on the day after oestrus. The maximum value was significantly different from basal values $(P<0 \cdot 01)$. There were no differences in observed values between heifers and cows. The progesterone concentration decreased from $9 \cdot 1 \mathrm{ng} / \mathrm{ml} 4$ days before oestrus to $0.35 \mathrm{ng} / \mathrm{ml}$ on the day of oestrus. The records of the fertility of these animals reported by Boyd \& Tasker (1971) showed that conception occurred in four animals.

The animals which received MGA alone came into oestrus within a period of 3 to 6 days after MGA withdrawal (average 4.8 days). Samples from six of these animals (five heifers and one cow) also exhibited a rising concentration 
of total oestrogens before oestrus (Text-fig. 2). The concentration increased from an average of $8.07 \mathrm{pg} / \mathrm{ml}( \pm 0.81)$ on the 4 th day before oestrus to 13.95 $\mathrm{pg} / \mathrm{ml}( \pm 3.36)$ on the day of oestrus. The seventh cow in this group had quite high concentrations of oestrogen, $20 \mathrm{pg} / \mathrm{ml}$ and $22.5 \mathrm{pg} / \mathrm{ml}$ on the day before and on the day of oestrus, respectively. The average progesterone concentration for the whole group is shown in Text-fig. 2. The large standard deviations for Days -4 and -3 reflect high progesterone concentrations in two animals which began MGA treatment on Day 21 and Day 0 of their previous cycle. Other animals had basal progesterone concentrations after MGA withdrawal. None of the MGA-treated animals conceived to first inseminations.

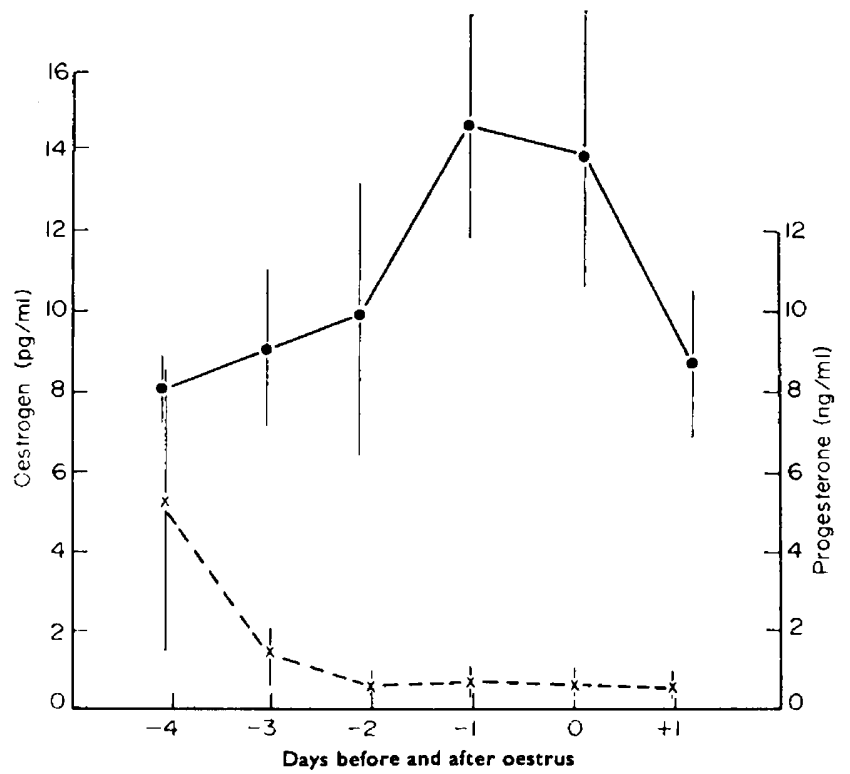

Text-fic. 2. Total oestrogen $(\bullet)$ and progesterone $(x)$ pattern before and after oestrus in animals (five heifers and one cow) treated with MGA alone.

Animals in Groups 3 and 4 were not observed for oestrus but were inseminated at a predetermined time. In the eight animals receiving MGA and HCG, the average concentrations of total oestrogens were $9.6 \mathrm{pg} / \mathrm{ml}$ on Day 2 and 10.4 $\mathrm{pg} / \mathrm{ml}$ on Day 3 after MGA withdrawal (Table 1). These concentrations were similar to the follicular phase concentrations of control and MGA-treated animals. Administration of HCG $72 \mathrm{hr}$ after MGA withdrawal apparently depressed the level of total oestrogens as the concentration on Day 4, when these animals were inseminated, was $8.6 \mathrm{pg} / \mathrm{ml}$. The only two animals in this group which did conceive to first insemination had a maximum oestrogen concentration concurrent with the HCG injection similar to that found in the control animals. The progesterone concentration was very low in six of the eight animals in this group (Table 2). One of the remaining two had concentrations of 5 to $8 \mathrm{ng} / \mathrm{ml}$ and did not return to oestrus for another 38 days; the other had a concentration of $8 \mathrm{ng} / \mathrm{ml}$ on Days 2 and 3 after MGA withdrawal which fell to $1 \mathrm{ng} / \mathrm{ml}$ on Day 4 and the animal returned to oestrus 18 
Table 1. Oestrogen concentration in peripheral plasma from control and treated cows and heifers

\begin{tabular}{|c|c|c|c|c|c|c|}
\hline & \multicolumn{6}{|c|}{ Days before or after oestrus } \\
\hline & -4 & -3 & -2 & -1 & 0 & +1 \\
\hline $\begin{array}{l}\text { Group } 1 \\
\text { (Controls) }\end{array}$ & $\begin{aligned} & 6 \cdot 60 \\
\pm & 1.8\end{aligned}$ & $\begin{aligned} & 9.00 \\
\pm & 1.8\end{aligned}$ & $\begin{array}{r}9.30 \\
\pm 3.3\end{array}$ & $\begin{array}{r}11 \cdot 1 \\
\pm 3.5\end{array}$ & $\begin{array}{l}13 \cdot 80 \\
\pm 2 \cdot 7\end{array}$ & $\begin{aligned} & 8 \cdot 90 \\
\pm & 2 \cdot 2\end{aligned}$ \\
\hline \multirow[t]{3}{*}{$\underset{(\mathrm{MGA})}{\text { Group } 2}$} & $\begin{array}{r}8.07 \\
\pm 0.81\end{array}$ & $\begin{array}{r}8.94 \\
\pm 2 \cdot 13\end{array}$ & $\begin{array}{r}9.65 \\
\pm 4.04 \\
\end{array}$ & $\begin{array}{r}14 \cdot 58 \\
\pm 3 \cdot 17\end{array}$ & $\begin{array}{r}13.95 \\
\pm 3.36\end{array}$ & $\begin{array}{r}8 \cdot 37 \\
\pm 1 \cdot 88\end{array}$ \\
\hline & & \multicolumn{5}{|c|}{ Days after last dose of $M G A$} \\
\hline & & & +2 & +3 & +4 & \\
\hline $\begin{array}{l}\text { Group } 3 \\
\text { (MGA + HCG) }\end{array}$ & & & $\begin{aligned} & 9 \cdot 62 \\
\pm & 5 \cdot 4\end{aligned}$ & $\begin{array}{r}10 \cdot 45 \\
\pm 6.45\end{array}$ & $\begin{array}{r}8 \cdot 6 \\
\pm 3.8\end{array}$ & \\
\hline $\begin{array}{l}\text { Group } 4 \\
(\text { MGA }+ \text { PMSG + HCG) }\end{array}$ & & & $\begin{array}{l}9 \cdot 50^{*} \\
\pm 5 \cdot 7\end{array}$ & $\begin{array}{l}11.50 \dagger \\
\pm 6.7\end{array}$ & $\begin{array}{l}11.70 \\
\pm 6 \cdot 2\end{array}$ & \\
\hline
\end{tabular}

Oestrogen concentrations expressed as $\mathrm{pg} / \mathrm{ml} \pm$ S.D. Group 2 excluding one cow with an abnormally high oestrogen concentration (see text).

* PMSG to Group 4. † HCG to Groups 3 and 4.

days later. These cows began MGA treatment on Days 4 and 10 of their previous oestrous cycles respectively.

In the animals receiving MGA + oestradiol + PMSG + HCG, the concentration of oestrogens on Day 2 after MGA withdrawal was $9.4 \mathrm{pg} / \mathrm{ml}$, which was similar to that in Group 3. In Day-3 samples, which were taken $3 \mathrm{hr}$ after the PMSG injection, the oestrogen concentration was $11.4 \mathrm{pg} / \mathrm{ml}$. On Day 4, following HCG injection, the total oestrogen concentration averaged 11.6 $\mathrm{pg} / \mathrm{ml}$. The progesterone concentration in seven of these animals was very low (Table 1); the eighth animal, for which treatment began on Day 2 of the

Table 2. Progesterone concentration in peripheral plasma from control and treated cows and heifers

\begin{tabular}{|c|c|c|c|c|c|c|}
\hline & \multicolumn{6}{|c|}{ Days before or after oestrus } \\
\hline & -4 & -3 & -2 & -1 & 0 & +1 \\
\hline $\begin{array}{l}\text { Group } 1 \\
\text { (Controls) }\end{array}$ & $\begin{aligned} & 9.06 \\
\pm & 1 \cdot 7\end{aligned}$ & $\begin{aligned} & 6 \cdot 64 \\
\pm & 2 \cdot 7\end{aligned}$ & $\begin{array}{l}1.51 \\
\pm 0.5\end{array}$ & $\begin{array}{l}0.55 \\
\pm 0.1\end{array}$ & $\begin{aligned} & 0.35 \\
\pm & 0.1\end{aligned}$ & $\begin{array}{l}0.22 \\
\pm 0.1\end{array}$ \\
\hline \multirow[t]{3}{*}{$\begin{array}{l}\text { Group } 2 \\
\text { (MGA) }\end{array}$} & $\begin{array}{l}5 \cdot 19 \\
\pm 3 \cdot 6\end{array}$ & $\begin{array}{ll} & 1.26 \\
\pm & 0.8\end{array}$ & $\begin{array}{l}0.28 \\
\pm 0.2 \\
\end{array}$ & $\begin{array}{l}0.35 \\
\pm 0.2 \\
\end{array}$ & $\begin{array}{l}0.26 \\
\pm 0.3\end{array}$ & $\begin{array}{ll} & 0.15 \\
\pm & 0.1\end{array}$ \\
\hline & & \multicolumn{5}{|c|}{ Days after last fetding of $M G A$} \\
\hline & & & +2 & +3 & +4 & \\
\hline $\begin{array}{l}\text { Group } 3 \\
\quad(\text { MGA + HCG) }\end{array}$ & & & $\begin{array}{r}0.15 \\
\pm 0.04\end{array}$ & $\begin{aligned} & 0.06 \dagger \\
\pm & 0.04\end{aligned}$ & $\begin{array}{r}0.09 \\
\pm 0.03\end{array}$ & \\
\hline $\begin{array}{l}\text { Group } 4 \\
\quad(\text { MGA }+ \text { PMSG + HCG) }\end{array}$ & & & $\begin{array}{l}0.17^{*} \\
\pm 0.09\end{array}$ & $\begin{aligned} & 0.12 \dagger \\
\pm & 0.04\end{aligned}$ & $\begin{array}{r}0.12 \\
\pm 0.05\end{array}$ & \\
\hline
\end{tabular}

Progesterone concentrations expressed as $\mathrm{ng} / \mathrm{ml} \pm$ S.D. Group 3 excluding two cows with abnormally high progesterone concentrations; Group 4 excluding one cow with an abnormally high progesterone concentration (see text).

* PMSG to Group 4. † HCG to Groups 3 and 4. 
previous cycle, had a concentration of $9 \mathrm{pg} / \mathrm{ml}$ in each sample after MGA treatment and came into oestrus 10 days after MGA withdrawal. Only one animal in Group 4 conceived.

\section{DISGUSSION}

In all of the groups treated with MGA, the oestrogen concentration in relation to onset of oestrus was not significantly different from that of the controls, with one exception, suggesting no adverse effect on the release of oestrogens from the ovarian follicles after the cessation of MGA treatment. The progesterone concentration was low on the day of oestrus as in the controls but differed from that of the controls in being low in most cases for several days before oestrus. The progesterone was higher than normal basal levels before oestrus for those animals which had MGA treatment superimposed on the normal corpus-luteum life-span, as calculated from previous heat dates. These results are contrary to those of Lamond, Dickey, Henricks, Hill \& Leland (1971) who reported progesterone concentrations in MGA-treated cows which were about $1 \mathrm{ng} / \mathrm{ml}$ higher than those usually found during the follicular phase. Similarly, Britt \& Ulberg (1972) found higher concentrations of progesterone, whereas Chow, Thatcher, Chenault, Kalra \& Wilcox (1972) found lower progesterone concentrations during the follicular phase compared to those of the controls. Chow et al. (1972) also found a higher average oestrogen concentration after MGA withdrawal.

It is suggested that an alteration in the ratio of progesterone to oestrogen before oestrus has led to infertility and this, along with an increased period of progestin influence in some animals, may be a cause of the reduced fertility at the first synchronized oestrus.

\section{ACKNOWLEDGMENTS}

The research was supported by a grant from the Agricultural Research Council.

The authors wish to express thanks to $\mathrm{Dr} \mathrm{B}$. V. Caldwell for the total oestrogen antibody SLC 6X and to Dr B. Furr for the progesterone antibody $465 / 4$. Melengestrol acetate was kindly supplied by Upjohn Limited. Oestradiol benzoate was kindly supplied by Organon Laboratories.

\section{REFERENCES}

Boyn, L. J. (1970) Effects of feeding MGA on occurrence of oestrus, fertility and milk yield in dairy cows. F. Anim. Sci. 31, 751.

BOyd, L. J. \& TASKeR, J. B. (1971) Fertility of oestrus synchronized dairy cattle treated with gonadotrophins and inseminated at a predetermined time. Vet. Rec. 89, 632.

BRITT, J. H. \& Ulberg, L. C. (1972) Melengestrol acetate administration to dairy heifers and progestagen levels in the peripheral blood plasma. J. Reprod. Fert. 29, 119.

Ghow, L. A., Thatcher, W. W., Ghenault, J. C., Kalra, P. S. \& Wilcox, C. J. (1972) Effects of MGa on bovine plasma ovarian steroids. $\mathcal{F}$. Anim. Sci. 35, 239.

Hotchkiss, J., Atkinson, L. E. \& Knobil, E. (1971) Time course of serum estrogen and luteinizing hormone (LH) concentrations during the menstrual cycle of the rhesus monkey. Endocrinology, 89, 177.

Lamond, D. R., Dickey, J. F., Henricks, D. M., Hill, J. R. \& Leland, T. M. (1971) Effect of progestin on the bovine ovary. J. Anim. Sci. 33, 77. 
Roussel, J. D., BeATtY, J. F. \& SMITH, T. L. (1969) Synchronization of oestrus in dairy heifers with MGA. J. Dairy Sci. 52, 905.

Wiltbank, J. N. \& Kasson, C. W. (1968) Synchronization of estrus in cattle with an oral progestational agent and an injection of an estrogen. 7. Anim. Sci. 27, 113.

Zimbelman, R. G. \& S SMTth, L. W. (1966a) Control of ovulation in cattle with melengestrol acetate. I. Effect of dosage and route of administration. J. Reprod. Fert. 11, 185.

Zimbelman, R. G. \& Smith, L. W. (1966b) Control of ovulation in cattle with melengestrol acetate. II. Effects on follicular size and activity. 7. Reprod. Fert. 11, 193. 